\title{
HATALMI JÁTSZMÁK A KULTURÁLIS ÖRÖKSÉGKÉPZÉSBEN ÉS A TUDOMÁNYOS KOMMUNIKÁCIÓBAN
}

Az MTA Könyvtárának közleményei címü sorozat új folyamának 41. köteteként jelent meg Monok István Könyvtári (?) problémák címú új könyve, mely széles müvelődéstörténeti kontextusba ágyazva tárgyalja a címben megnevezett, sok évszázados múltra visszatekintő intézményrendszer korábbi helyzetét, illetve a jelenben és a közeljövőben elötte álló kihívásokat.

Az emberiség régi vágya, hogy a múltban felhalmozott és az újonnan keletkező tudást - aere perennius - ércnél maradandóbban megőrizze. A kulturális örökség összegyüjtése és megőrzése érdekében különféle társadalmi képződmények - levéltárak, könyvtárak - jöttek létre, amelyek sok évszázadon át magántulajdonban voltak. A 19-20. században számos örökségőrző gyüjtemény a közfinanszírozású állami intézményrendszer részévé vált. A könyvtárak, levéltárak, múzeumok és bizonyos archívumok gyüjtőnevei: örökségképző vagy memóriaintézmény. Nálunk hosszú ideje közgyüjteménynek nevezik a kulturális örökség örzésére kijelölt, az adófizetők pénzéből fenntartott intézményeket.

Az írás, az írásbeliség és a könyv társadalmiasulásának módozatai, e folyamatok történései a különböző kulturális zónák, a különféle világvallások történetével párhuzamosan mennek végbe. Mindennek következményeként a nyomtatott kulturális örökség letéteményese, a könyvtár mindig is a hatalmi játszmák részese volt. Az egyes történelmi korszakokban a mindenkori hatalom legföképpen a gyüjtemények nyilvánosságát akarta meghatározni. A fő kérdés: „ki birtokolja a kultúrát?".

A könyvtári intézményrendszer - többek között - gyüjti és őrzi a tudományos publikációkat. A hatalmi viszonyok és a döntéshozók szándékai szerint biztosított anyagi erőforrások határozzák meg, mely könyvtár milyen gyüjteményt tud kialakítani, mennyire képes a legújabb információforrásokat összegyüjteni, vagy - újabban - ezekhez a hozzáférést biztosítani. A mai informatikai eszközök azt az ígéretet hordozzák, hogy a tudomány teljessége áttekinthető, a tudományos eredmények és a kulturális hagyomány megismerhetö.

A kutatókat különösképpen érintik a változó politikai erőtérben kialakuló, a tudományos információk megosztását meghatározó új hatalmi relációk. Többféle érdek füződik a tudományos kommunikáció csatornáinak, a szakterületi publikációk közzétételének és a kereshetőségét biztosító adatbázisoknak ellenőrzés alatt tartásához. Aki ezen a téren sikert ér el, annak biztos helye lesz a jövő hatalmasai között. Ma meghatározott tőkés körök monopolizálják a világ információpiacát. 
„Ennek a piacnak a monopóliumai öt-hat nagyobb kiadói - pontosabban csupán pénzügyi befektetői - csoport kezében vannak, és ugyanezek a csoportok alapjaiban befolyásolják a tudományértékelés szempontrendszerét, az egyes kiadványok nemzetközi súlyát, és ezen keresztül a kiadványokat tartalommal megtöltő intézmények és személyek tudományos sorrendjét (ranking) is" - írja a szerző.

Az értelmiséggel szövetkező kiadói világ anyagi érdekeiben azonban ma éppúgy veszélyeztetve érzi magát, mint ahogy a 15 . századi másoló céhek féltették - okkal-joggal - helyzetüket a könyvnyomtatástól. „Az internet business ma nagyobb, mint az egyházi business valaha is volt." Szereplöinek semmivel sem tisztább a szándéka, mint az egyházé volt a középkorban vagy a korai újkorban. Tény, hogy az online üzlet szereplői hatalmas hozzáadott értéket hoznak létre, de el is várják ennek pénzügyi megtérülését. „A kérdés az, hogy a tudományos információknak az a köre, amelyet ők most forgalmaznak, mennyiben az övék (erkölcsileg és jogilag)." Ma a világ tudományos információinak csaknem 90\%-a az Elsevier, a Clarivate (Thomson Reuters), az EBSCO és a ProQuest tulajdona.

Ki gondolná, hogy a jelenleg oly széles körben terjedő open access melletti hitvallás már a 17. század közepén megszületett? A könyvtártudomány megalapozója, Gabriel Naudé azt vallotta, a tudományos alkotás lehetetlenné válik, és nem jöhetnek létre új, modern alkotások, ha a kortárs kutatók nem férhetnek hozzá teljes mértékben az elmúlt idők eredményeihez.

Ami a kulturális örökség digitális megjelenítését illeti, Monok István véleménye szerint az Európai Unióban e területen több egymásnak feszülő érdek fogalmazódott meg. A megegyezés alapvető akadálya: az EU nem a közös európai öntudattal rendelkező közösségek együttmüködése mentén, hanem egy közös piac megalakításának érdekében jött létre. Monok István szerint „A politikusok anélkül szajkózzák az európai érték kifejezést, hogy valaha kísérletet tett volna a »közösség “ arra, hogy megfogalmazza, melyek ezek az értékek”, és vélhetően nem is tudnának egy „érték-katalógusban” megállapodni. „Érdek és erő (ki győzött a háborúban) alapon gondolkodva soha nem lehet érték-katalógust összeállítani."

Súlyos, nehéz szavak, akárcsak a következők, melyek igazságtartalmát az internetet (vagyis a vele azonosított World Wide Webet) a születésétöl fogva ismerők nem vonják kétségbe. „Az internet demokratikusnak képzeltetett el” - írja a szerző. És mivé vált mára? - kérdezi a recenzens. A világháló elvileg ugyan magában hordozza a demokrácia lehetőségét, a jelenlegi gyakorlat azonban maga a megtestesült hipercenzúra.

A történelem folyamán nem először vetődnek föl hasonló kérdések; az összes jelentős kommunikációtechnológiai változás során a hatalmi érdekek érvényesültek: a kulturális javak és/vagy azok másolatának a birtoklása, közreadásának joga mindig és mindenkor a hatalomra jutók kezébe került.

A kötet szerzöje a Magyar Tudományos Akadémia Könyvtárának jelenlegi és az Országos Széchényi Könyvtár korábbi föigazgatója, egyetemi tanár, nemzet- 
közi hírü könyvtörténész. Bár Monok István az egyik jól ismert intézménytípust, a könyvtárat nevezi meg új kötetének címében, a könyv azonban sokkal inkább a kulturális örökségképzés által az európai eszme- és művelődéstörténetben betöltött szerep nagyívü áttekintése, mintsem a könyvtárak problémáira koncentráló szakkönyv. A szerző nyomatékosan hangsúlyozza: ,a könyvtárak gondjai a mindenkori emberi közösségek egészének a gondjai. A problémák megoldásának a kulcsát nem a könyvtári megoldásban látom, hanem a társadalom értékviszonyainak a kritikus vizsgálatában.”

A kérdéskör iránt érdeklődők a 40 oldalas bibliográfiát áttekintve számos további szakirodalmi forrást tudnak tanulmányozni. A kötetet név- és tárgymutató, továbbá a Monok István könyvtárügyi írásait felsoroló bibliográfia egészíti ki.

Természetesen a címben jelzett könyvtári problémákról is sok szó esik a könyvben, de a szerkesztésnek köszönhetően a könyvtárügyi témák látványosan elkülönülnek a művelődéstörténeti eszmefuttatásoktól. A szerző szellemes megoldása azokat az olvasókat, akik kevéssé érdeklődnek az adatbázisok, a kötelespéldányok vagy éppen a könyvtárosképzés aktuális kérdései iránt, szinte „felmenti” az egyes, szüken vett szakmai fejezetek olvasása alól.

A tudományos információk megosztásában kialakult hatalmi viszonyrendszer sajátosságai, a mủvelődési eszményeknek, illetve a tudás mintázatainak változásai iránt érdeklődő olvasóknak mindenképpen kézbe kell venniük ezt az elgondolkodtató, szellemi izgalmakban bővelkedő kötetet.

(Monok István: Könyvtári (?) problémák. [A Magyar Tudományos Akadémia Könyvtárának közleményei 41.] Budapest: MTAK, 2020, 272 o.

E-könyv: DOI 10.36820/MTAKIK.KOZL.2020.KONYVTAR, http://real-eod.mtak. hu/9274/1/Monok_ktros_DOI2.pdf)

Tószegi Zsuzsanna

PhD, címzetes egyetemi docens Eötvös Loránd Tudományegyetem Bölcsészettudományi Kar Könyvtár- és Információtudományi Intézet 